\title{
Helical Cell Wall Thickenings in Root Cortical Cells of Polypodiaceae Species from Northwestern Argentina
}

\author{
Marcela A. Hernández, Lucrecia Terán, and Marisol Mata \\ Instituto de Morfología Vegetal, Fundación Miguel Lillo, Miguel Lillo, 251, 4000, Tucumán, \\ Argentina, e-mail: marcela.alicia.hernandez@gmail.com
}

Olga G. Martínez

IBIGEO, Herbario MCNS, Facultad de Ciencias Naturales, Universidad Nacional de Salta, CP 4400, Salta, Argentina

JEFFERSON PRADO

Herbário SP, Instituto de Botânica, Av. Miguel Estéfano, 3687, CEP 04301-012, São Paulo, SP, Brazil

\begin{abstract}
The occurrence of helical cell wall thickenings in fern roots is not well investigated and there are few records about it in the literature. To assess the presence of thickenings and their chemical composition, we studied all species of Polypodiaceae, which grow in northwestern Argentina, using light microscopy, scanning electron microscopy, and fluorescence microscopy. Twenty of the twenty-one species studied showed the thickening in the roots. Only in Melpomene peruviana are helical cell wall thickenings absent. All thickenings have cellulose as the main compound. The structure of the thickening may be classified as simple, furcate, or anastomosing. All data presented in this paper corroborate the same structure and chemical composition of thickenings previously reported for Aspleniaceae.
\end{abstract}

KEY WoRDs.-Anatomy, Eupolypods I, ferns, epiphytes, cellulose

The presence of a tissue similar to the velamen has been previously recorded in the outer cortical zone of roots for some Polypodiaceae. Geisenhagen (1901, apud Pandé, 1935) was the first author to describe helical thickenings in cell walls of ferns, namely Niphobolus penangianus Hook. Also Pandé (1935) reported thickenings in the root cortical parenchymatic cells of Niphobolus adnacens (Sw.) Kaulf. (= Pyrrosia lanceolata (L.) Farw.), and observed pits in the cell wall between these thickenings. These thickenings appear as strands internally in the cells. Ogura (1972) reported something similar for roots of Pyrrosia, but gave no details.

Schneider (1997) studied the root anatomy of the Aspleniaceae and reported spiral wall thickenings in the outer cortex of some species. He mentioned that these thickenings can also be found in epiphytic ferns such as Grammitidaceae, Polypodiaceae, and in some Vittariaceae, but he did not present additional details. He suggested that these cells with helical thickenings function like the cells of the velamen of Orchidaceae.

Recently, Leroux et al. (2011) investigated the structure of these root cortical cells for 96 specimens (representing 72 species) of Aspleniaceae and designated them as helical cell wall thickenings (henceforth called 'thickenings'). These authors defined them as simple helical thickenings that branch dichotomously, sometimes forming a net-like pattern. They also determined 
the chemical composition of the thickenings and found that they are composed of homogalacturonan, cellulose, mannan, and xyloglucan. They found the thickenings in 43 specimens (28 species) of Asplenium examined.

Silva et al. (2011) have found similar chemical composition for primary cell walls in the leaves of ferns and lycophytes. They suggested that ferns present a third type of cell wall, composed mainly by mannan. In the same paper, details of this chemical cell wall were presented for Adiantum raddianum C. Presl. (Pteridaceae).

According to Smith et al. (2006), Polypodiaceae is primarily Pantropical, with some species occurring in temperate regions. It contains about 56 genera and 1200 species. Mostly species are epiphytic but some are saxicolous, and rarely are there terrestrial ones. Polypodiaceae sensu Smith et al. (2006) encompass the grammitid ferns, which were previously segregated in their own family, the Grammitidaceae (e.g., Ranker et al., 2004; Schneider et al., 2004a).

Investigations carried out over the past ten years on fern classification (e.g., Smith et al., 2006; Christenhusz et al., 2011) and phylogeny and evolution (e.g., Hasebe et al., 1994, 1995; Pryer et al., 1995, 2001, 2004; Schneider et al., 2004b; Schuettpelz and Pryer 2007; Rothfels et al., 2012) based on molecular and morphological data, improved greatly our knowledge about relationships among the major lineages of ferns, but in none of these studies was the presence of the thickenings cited in Polypodiaceae (Eupolypods I) or Aspleniaceae (Eupolypods II).

During the investigation of the sporophyte anatomy of Pleopeltis minima (Bory) J. Prado \& R.H. Hirai (Prado and Hirai, 2010), the thickenings in the root parenchymatic cortical cells came to our attention, because there were no recent reports of them in the literature for the Polypodiaceae. Thus, we widened our investigations to include all other species of the family that grow in northwestern Argentina.

The present study has two main goals: First, investigate the presence of thickenings in all species of Polypodiaceae from northwestern Argentina; second, determine their forms and chemical composition, as well as discuss their importance in ferns.

\section{Materials AND Methods}

The specimens studied in this work came from LIL, MCNS, and LP herbaria, and living plants collected by the authors from several localities in northwestern Argentina. Vouchers for all recently collected species were deposited at LIL and MCNS (Table 1). Root fragments of the specimens were sampled for the anatomical and histochemical studies (Table 1, Figs. 1, 3, 4, 5).

Light microscopy.-Anatomical specimens were prepared with dried and fixed material. All material removed from the herbarium specimens was rehydrated in boiling water to which a few drops of detergent had been added, and left at $30^{\circ} \mathrm{C}$ into oven for 24 hours. 
To observe the isolated cells containing the wall thickenings, the root tissues were macerated using a mixture of nitric acid plus water (1:1), at room temperature for 25-30 days. The dissociated material was washed five times with distilled water, and stained with Astra Blue (Biopack) and alcoholic Safranine O (basic red) solution (1\%).

To determine the chemical composition of the thickenings in root cortical cells, the material was sectioned by hand longitudinally and transversally, and coloured with different polychromatic dyes: aquatic solution 1\% of Cresyl Violet and $1 \%$ aquatic solution of Cresyl Blue.

To evaluate the width of the thickenings and their number per cell, 10 measurements were made from each specimen, selecting in all cases the five thickest roots of each individual. Maximum and minimum values as well as average and standard deviation were obtained for each species studied (Table 2, Fig. 2A-B).

To test for the presence of lignin in the thickenings, transverse and longitudinal sections were stained with phloroglucinol (1\%) with $\mathrm{HCl}(25 \%)$ (D’Ambrogio de Argüeso, 1986). Also, a differential coloration stain was used: Safranine (1\%) and Astra Blue (0.5\%) (Bruno et al., 2007).

To evaluate the presence of cellulose as the principal chemical component of the - thickenings in root cortical cells, hand-cut longitudinal sections were clarified in a solution of commercial sodium hypochlorite plus water (1:1). After being clarified, the sections were washed five or six times with distilled water and mounted on slides containing $0.05 \%$ weight/volume solution of optical fluorescent brightener 28 calcofluor in a sodium phosphate buffer at pH 8 (Romero and Minter, 1988). This fluorescent dye reacts with cellulose. These slides were observed under an Olympus BX51 light microscope with UV filter to fluorescence and under refrigerated camera Olympus DP72. Photographs of the sections were taken in conditions of fluorescence, light, and darkness. In order to obtain cell measurements the software Olympus Cellsens was used. Basically, the width of the thickenings were measured for each species (Table 2).

To test for the presence of suberin in the thickenings, transverse and longitudinal fresh sections of roots were put in ethanol for a few seconds. Later, they were incubated for 5-10 minutes in fresh Sudan III or IV alcoholic solution (2\%); differentiated with ethanol $50 \%$ and mounted in glycerine (Ruzin, 1999).

All the semi-permanent slides were mounted with water plus glycerine (1:1).

Other observations and photographs were taken under light microscopy Standard 16 Zeiss and Zeiss Axiostar with a camera Cannon Powershot A620 of 7.2 MP attached, plus a Software Cannon Powershot and Olympus CX41 microscope with a digital camera Mshot (MC30). Measurements were performed with the software Mshot Digital Imaging System, at a magnification of $630 \mathrm{X}$.

Scanning electron microscopy.-Longitudinal hand-cut sections of roots were fixed with $2 \%$ glutaraldehyde in phosphate buffer for 72 hours and dehydrated in a graded ethanol series $(50 \%, 70 \%, 90 \%, 100 \%$, for $20 \mathrm{~min}$. in each solution). After fixation and dehydration the samples were critical point dried with carbon dioxide (Denton Vacuum DCP-1). Dried sections were fixed 


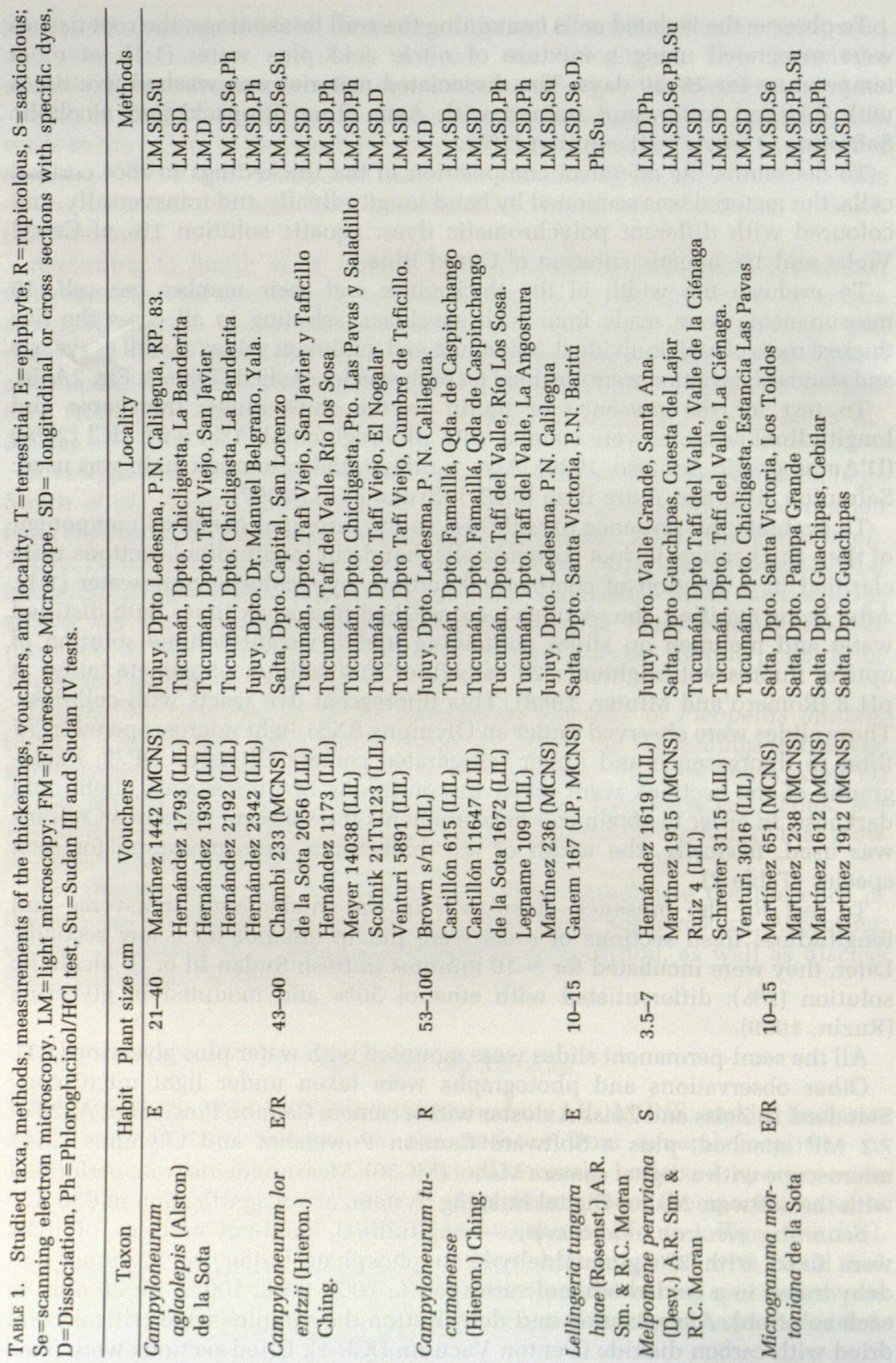




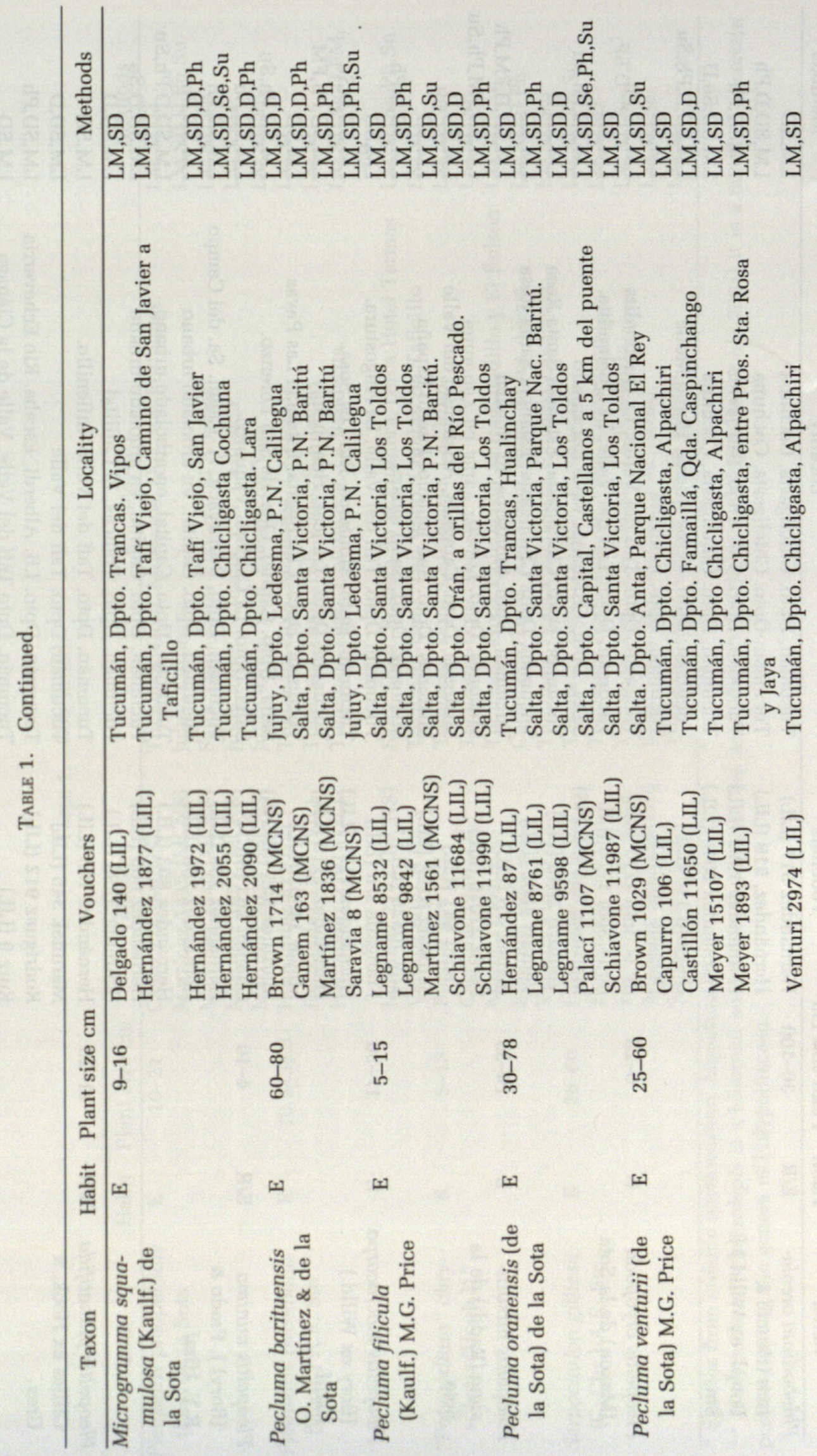




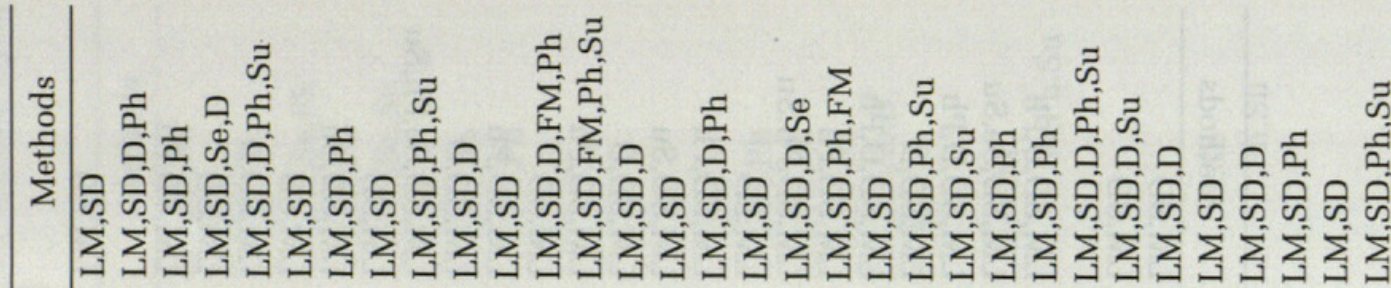

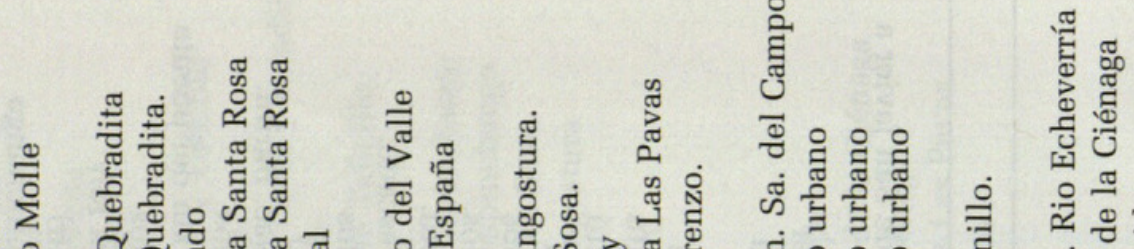

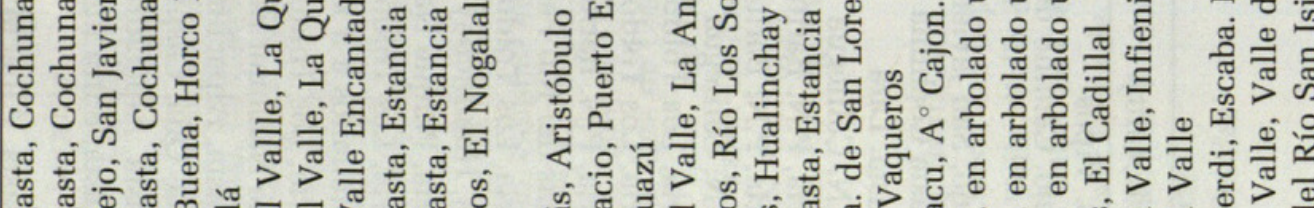

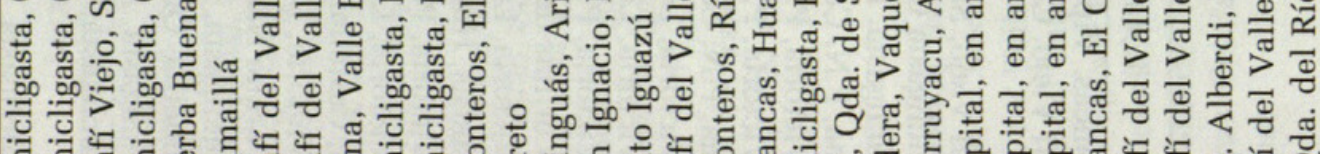

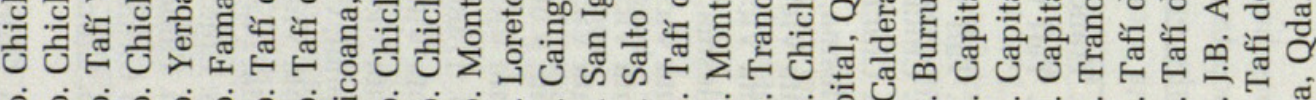

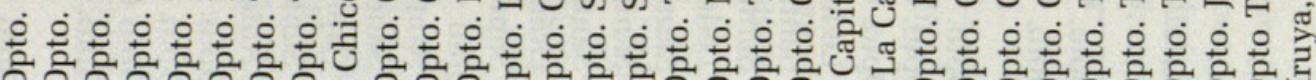

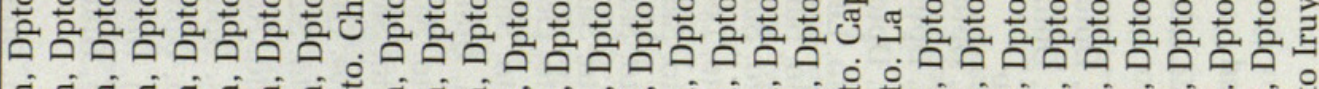

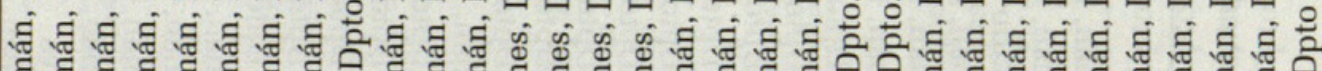

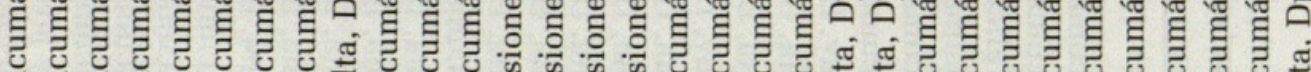

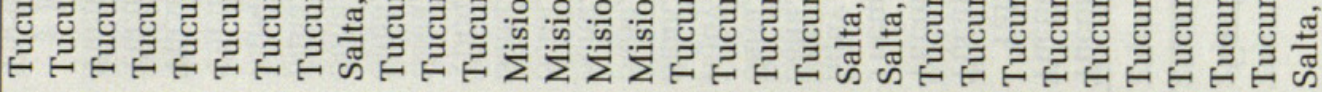

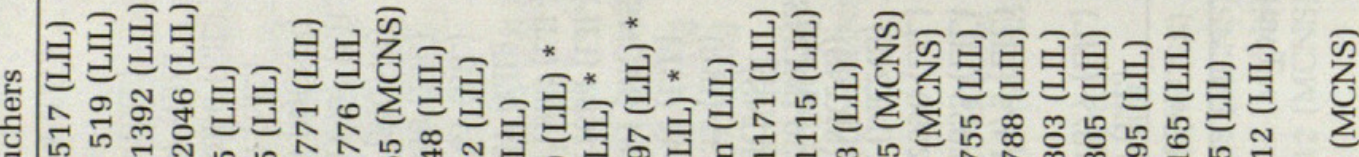

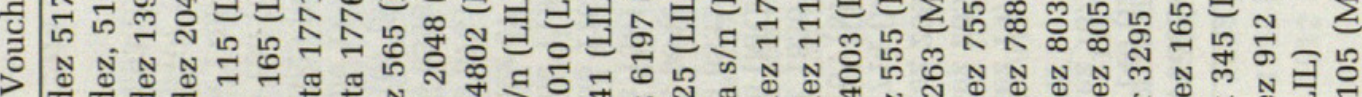

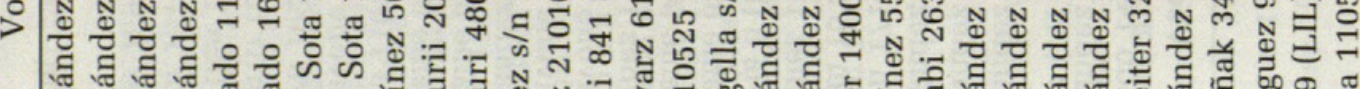

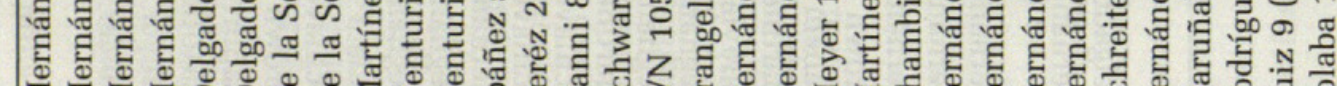
ีㅡㅇ

ฟิ
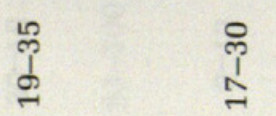

[x工

도

$\frac{1}{x}$

$\frac{1}{19}$

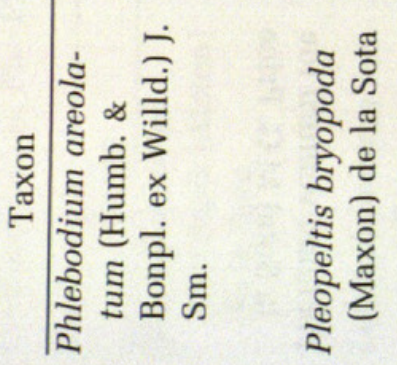

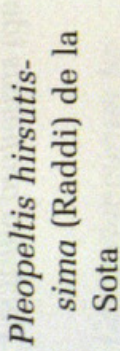

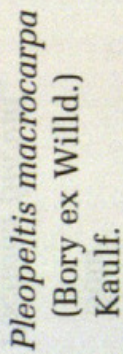

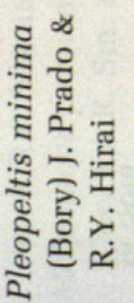

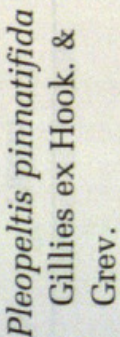




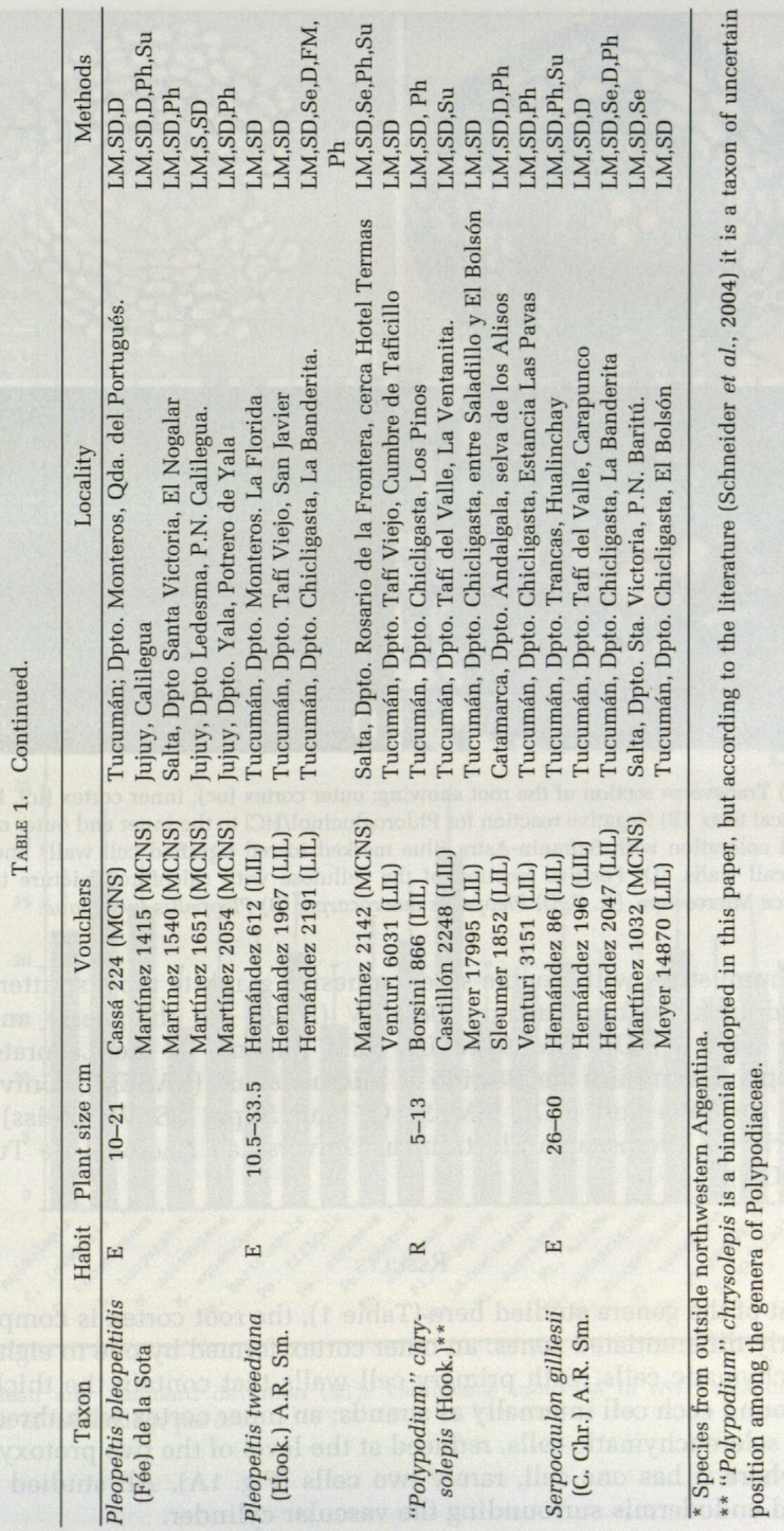



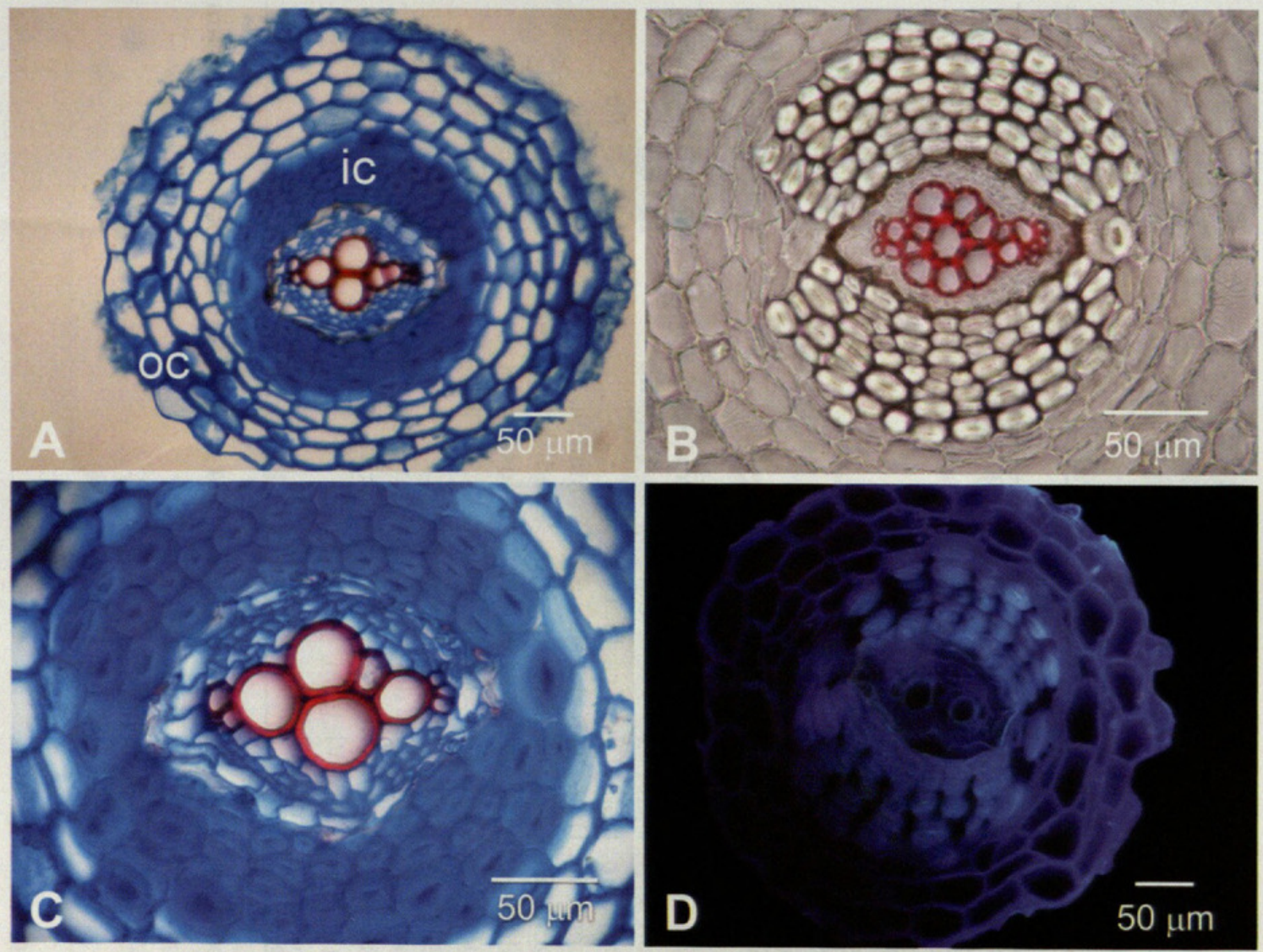

FIG. 1. (A) Transverse section of the root showing: outer cortex (oc), inner cortex (ic). Result for histochemical tests. (B) Negative reaction for Phloroglucinol/HCl to the inner and outer cortex. (C) Differential coloration with Safranin-Astra Blue marked in red lignified cell walls and in blue cellulosic cell walls. (D) Positive reaction of the cellulose with calcofluor, picture took from Fluorescence Microscope. (A, C, D) Pleopeltis macrocarpa; (B) Pleopeltis tweediana.

on aluminum stubs with double-sided adhesive graphite tape, sputter-coated with gold in a Denton Vacuum Desk IV (20-24 nm thickness) and were observed with a JEOL JSM 6480 LV SEM (Japan), in the Laboratorio de Microscopía Electrónica de Barrido y Microanálisis (LASEM), Universidad Nacional de Salta and JEOL JSM 35 CF and Supra SS VP (Zeiss) in the Laboratorio de Microscopía Electrónica, Universidad Nacional de Tucumán (LAMENOA).

\section{RESULTS}

In eight of the genera studied here (Table 1), the root cortex is composed of two clearly differentiated zones: an outer cortex formed by one to eight layers of parenchymatic cells, with primary cell walls that contain the thickenings that surround each cell internally as strands; an inner cortex with three to five layers of sclerenchymatic cells, reduced at the level of the two protoxylematic points where it has one cell, rarely two cells (Fig. 1A). All studied species presented endodermis surrounding the vascular cylinder. 

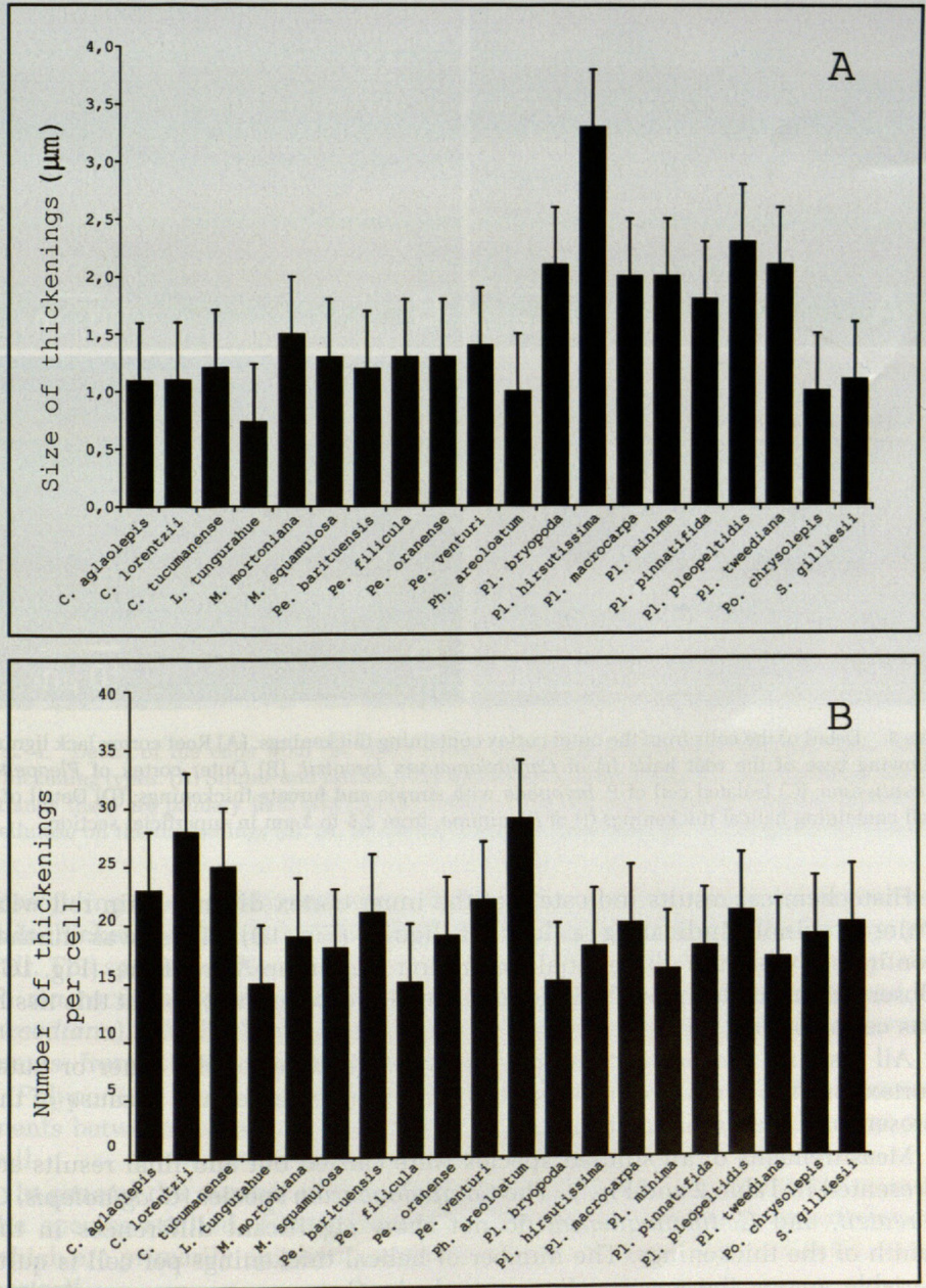

Fig. 2. Mean and Standard deviation (95\% confidence intervals) of (A) Thickening's size; (B) Number of thickenings per cell. 

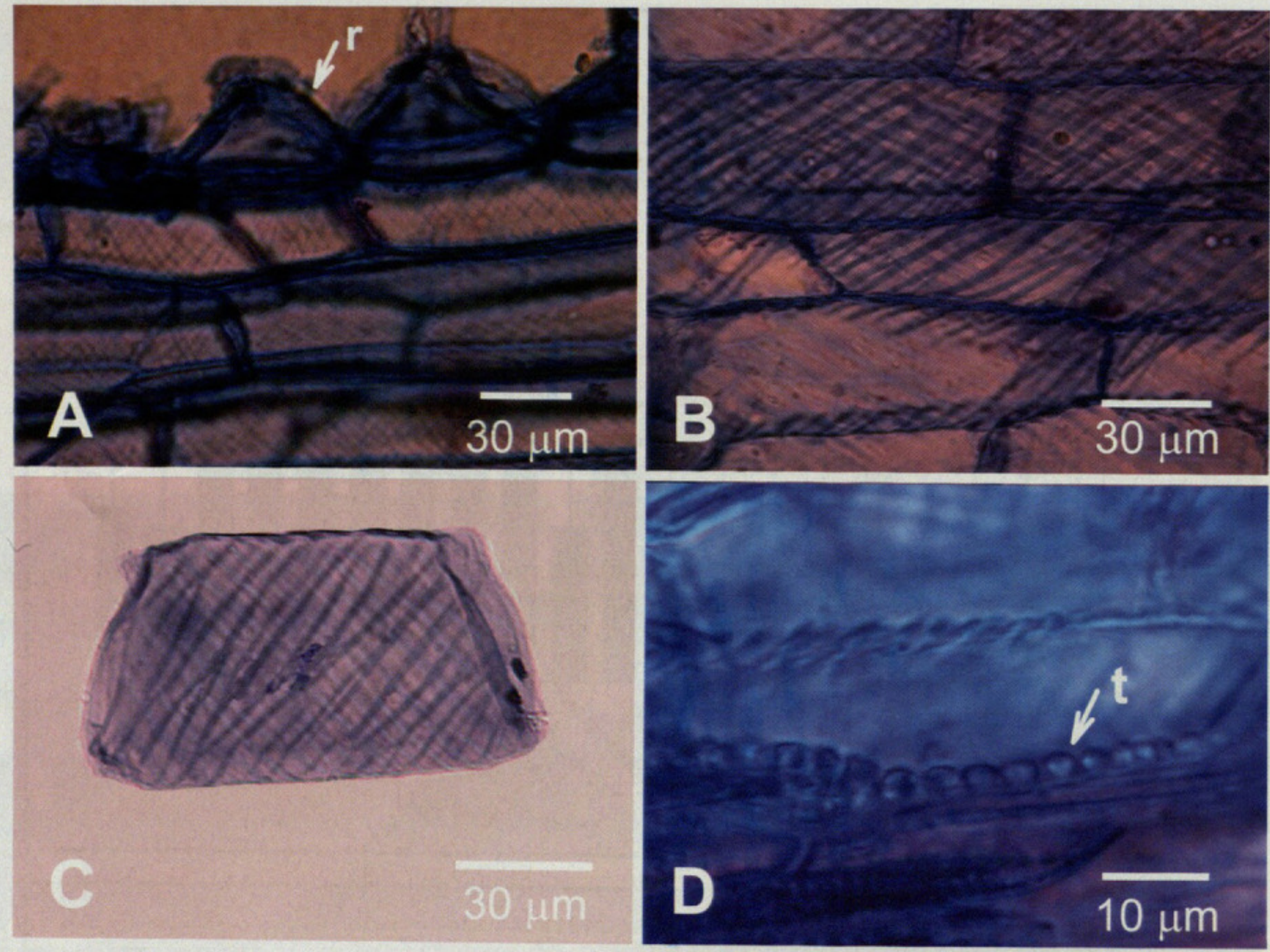

FIG. 3. Detail of the cells from the outer cortex containing thickenings. (A) Root cortex lack lignin, showing base of the root hairs (r) of Campyloneurum lorentzii; (B) Outer cortex of Pleopeltis hirsutissima; (C) Isolated cell of $P$. bryopoda with simple and furcate thickenings; (D) Detail of a cell containing helical thickenings (t) of $P$. minima, from 2.5 to $3 \mu \mathrm{m}$ in superficial section.

Histochemical results indicate that the inner cortex did not stain red with Phloroglucinol, indicating a lack of lignin (Fig. 1B). This was further confirmed with the differential coloration Safranine-Astra Blue (Fig. 1C). Observations made under the Fluorescence Microscope showed that this tissue has cellulose (Fig. 1D).

All tests for the presence of suberin were negative for the inner or outer cortex, but the overall result was positive for the endodermis, because of the presence of the Casparian bands.

Measurements of all studied species were carried out and final results are presented in Table 2 and Fig. 2. The Campyloneurum species (C. aglaolepis, $C$. lorentzii, and C. tucumanense) do not show significant differences in the width of the thickenings. The number of helical thickenings per cell is quite variable among the species. For example in C. tucumanense, a rupicolous species, there are 9-45 thickenings per cell, whereas C. lorentzii (Fig. 3A), an epiphytic or rupicolous species 17-40 strands. Compared to other species, Lellingeria tunguraguae showed the narrowest thickenings $(0.5-1.2 \mu \mathrm{m})$ and least number of thickenings per cell. The species of Pecluma ( $P$. barituensis, $P$. filicula, $P$. oranensis, and $P$. venturii), all epiphytes, have similar thickenings, 

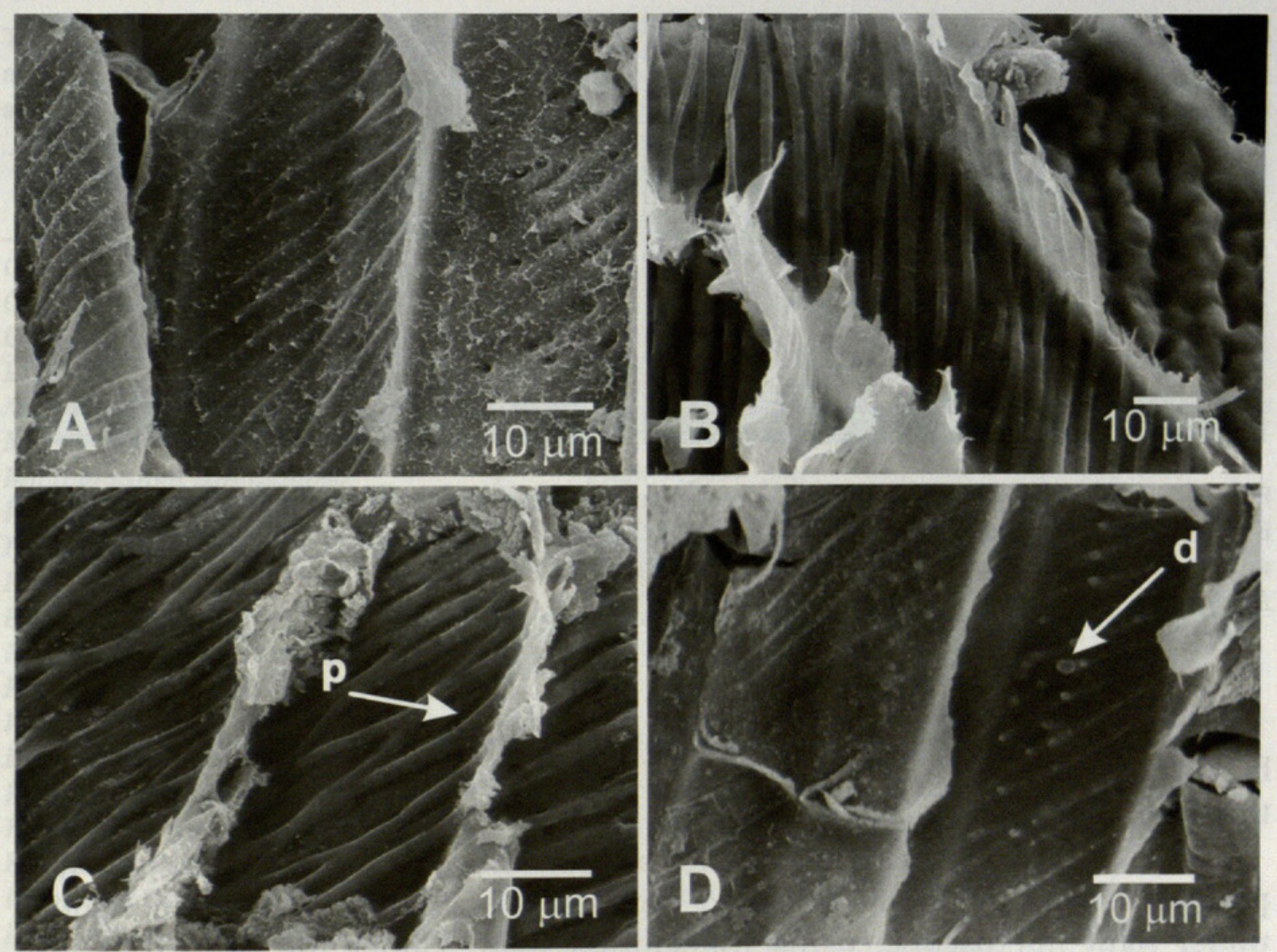

Fig. 4. Detail of the cells from the outer cortex containing thickenings observed under SEM. Thickening types. (A) Simple and furcate; (B) Furcate and anastomosing; (C) Anastomosing, among strands there are primary field pits (p); (D) Detail of the cell wall showing irregular deposits of cellulose on the thickenings (d). (A, D) Campyloneurum aglaolepis; (B, C) Pleopeltis tweediana.

resembling those of Microgramma. Phlebodium areolatum (also epiphytic) has thin thickenings (about $1.0 \mu \mathrm{m}$ wide) and the biggest amount of thickenings per cell. The species of Pleopeltis (P. hirsutissima (Fig. 3B), P. bryopoda (Fig. 3C), $P$. macrocarpa, $P$. minima (Fig. 3D), $P$. pinnatifida, $P$. pleopeltidis, and $P$. tweediana), all of which are epiphytic, had the largest thickenings measurements, from 0.9-4.4 $\mu \mathrm{m}$ wide (Table 2).

Polypodium chrysolepis and Serpocaulon gilliesii showed similar measurements between them in relation to the width and number of thickenings per cell.

In general the number of thickenings per cell varies from 15-25 for most of the species studied. Campyloneurum lorentzii and Phlebodium areolatum, which are primarily epiphytic or rarely rupicolous, have about 30 thickenings per cell.

Most of the species studied had thickenings that were simple or furcate (Table 2). Pleopeltis bryopoda, a saxicolous fern, has more furcate thickenings than simple ones, and there are several per cell. Some of the furcate thickenings joined each other, but did not form a net or reticulum. This kind of anastomosing is present in $50 \%$ of the analyzed taxa (Fig. $4 \mathrm{~A}-\mathrm{C}$ ). 

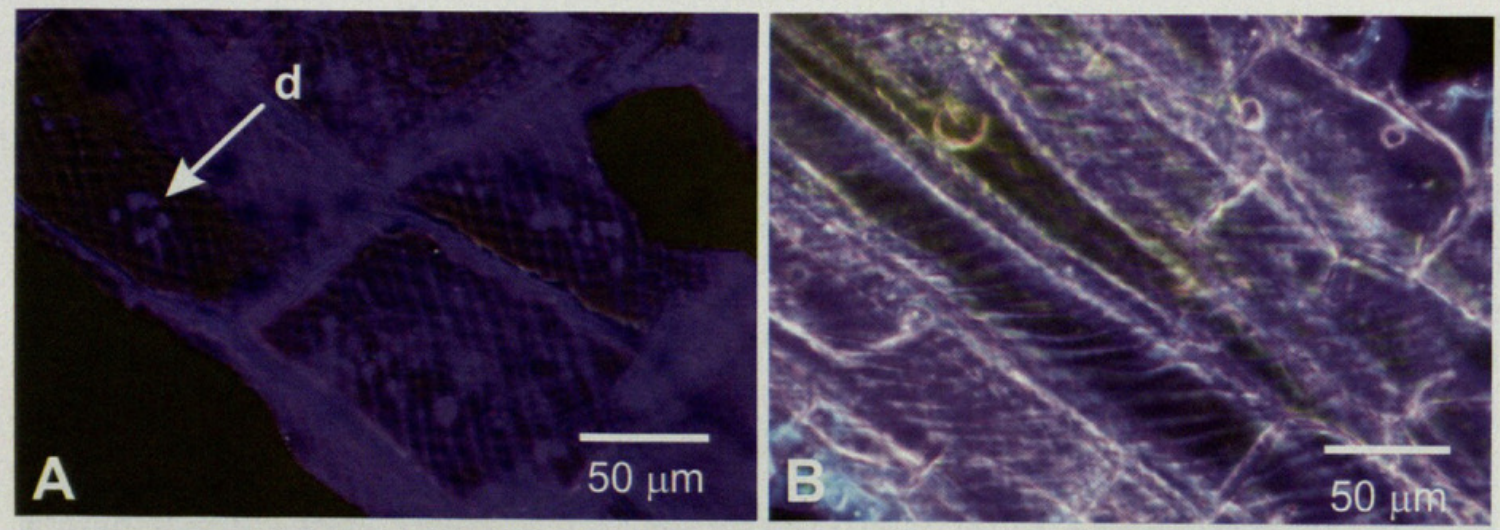

FIG. 5. Details of the cells from the outer cortex containing thickenings observed under Fluorescence Microscope using calcofluor. (A) Cellulosic thickenings of Pleopeltis macrocarpa with spherical deposits on the thickenings (d); (B) Positive reaction of the cellulosic thickenings of Pleopeltis hirsutissima.

The cells with thickenings have primary pit fields in the primary cell walls between the thickenings (Fig. 4C). Pits do not occur on the secondary wall of the thickenings.

The deposition of cellulose on these thickenings is not uniform, and it is possible to observe some rounded deposits of cellulose in certain regions under light microscope, using transmitted light. Under the SEM it is also possible to observe these rounded accumulations of cellulose on the thickenings (Figs. 4D, 5A).

The results of the staining tests revealed that the thickenings are composed mainly of cellulose. This was most evident by a positive reaction to the test with calcofluor and posterior observation under the fluorescence microscope (Fig. 5B). All tests for lignin were negative. Applying the Phloroglucinol/HCl test and the Safranine-Astra Blue double stains, the same result was also observed, the sclerenchymatic tissue situated in the inner cortex also lack lignin in their secondary walls.

Among all studied species, Melpomene peruviana is uniquely without thickenings in the outer cortex. But, in the other aspects its roots are morphologically similar to all investigated species in this paper. Its inner cortex has a sclerenchymatic zone and the outer cortex has cells uniformly thickened, but not forming the helical arrangement of cellulose. Initially we though that the absence of thickenings in this species could be related to its saxicolous habit, but another saxicolous species, Pleopeltis bryopoda, that grows together with $M$. peruviana has outer cortex with thickenings. Thus, the data suggest that there is no known correlation between the habit vs. absence of thickenings.

The results showed that the widest thickenings are found in the species of Pleopeltis, more specifically, in $P$. hirsutissima, that has the thickenings varying from 1.0 to $4.4 \mu \mathrm{m}$ width and the narrowest ones appear in Lellingeria tunguraguae (0.5-1.2 $\mu \mathrm{m})$ (Table 2). Both P. hirsutissima and L. tunguraguae 
TABLE 2. Measurements and characteristics of the HCWT for each studied species. Minimum, average, and maximum values, plus the standard deviation and type of thickenings present in each species $(\mathrm{S}=$ simple; $\mathrm{F}=$ furcate; $\mathrm{A}=$ anastomosing).

\begin{tabular}{|c|c|c|c|c|c|c|c|c|}
\hline \multirow{2}{*}{$\frac{\text { Species }}{\text { Campyloneurum aglaolepis }}$} & \multirow{2}{*}{$\begin{array}{c}\begin{array}{c}\text { Helical } \\
\text { thickenings }\end{array} \\
+\end{array}$} & \multicolumn{2}{|c|}{$\begin{array}{l}\text { Width of the } \\
\text { thickenings }(\mu \mathrm{m})\end{array}$} & \multicolumn{2}{|c|}{$\begin{array}{l}\text { Number of thick- } \\
\text { enings per cell }\end{array}$} & & \multirow{2}{*}{$\frac{F}{+}$} & \multirow{2}{*}{$\frac{A}{-}$} \\
\hline & & $0.6(1.1) 2.1$ & 0.4 & $13(23) 35$ & 2.3 & & & \\
\hline Campyloneurum lorentzii & + & $0.6(1.1) 1.8$ & 0.2 & $17(28) 40$ & 5.3 & + & + & - \\
\hline Campyloneurum tucumanense & + & $0.6(1.2) 2.3$ & 0.3 & $9(25) 45$ & 8.9 & + & + & + \\
\hline Lellingeria tunguraguae & + & $0.5(0.7) 1.2$ & 0.2 & $12(15) 21$ & 3.7 & + & + & - \\
\hline Melpomene peruviana & - & - & - & - & - & - & - & - \\
\hline Microgramma mortoniana & + & $0.7(1.5) 2.4$ & 0.1 & $13(19) 28$ & 1.2 & + & + & + \\
\hline Microgramma squamulosa & + & $0.6(1.3) 2.9$ & 0.4 & $12(18) 28$ & 1.5 & + & + & + \\
\hline Pecluma barituensis & + & $0.8(1.2) 2.4$ & 0.4 & $16(21) 29$ & 2.1 & + & + & - \\
\hline Pecluma filicula & + & $0.8(1.3) 2.2$ & 0.1 & $9(15) 21$ & 2.2 & + & + & - \\
\hline Pecluma oranensis & + & $0.8(1.3) 1.9$ & 0.1 & $15(19) 28$ & 1.6 & + & + & - \\
\hline Pecluma venturii & + & $0.9(1.4) 2.2$ & 0.1 & $11(22) 35$ & 3.5 & + & + & - \\
\hline Phlebodium areolatum & + & $0.6(1.0) 1.5$ & 0.2 & $18(29) 36$ & 2.7 & + & + & + \\
\hline Pleopeltis bryopoda & + & $0.9(2.1) 4.1$ & 0.4 & $8(15) 23$ & 2.8 & + & $t^{\star}$ & - \\
\hline Pleopeltis hirsutissima & + & $2.4(3.3) 4.4$ & 0.2 & $13(18) 24$ & 0.2 & + & + & + \\
\hline Pleopeltis macrocarpa & + & $0.9(2.0) 3.8$ & 0.4 & $10(20) 26$ & 2.7 & + & + & + \\
\hline Pleopeltis minima & + & $1.0(2.0) 3.3$ & 0.3 & $11(16) 26$ & 0.8 & + & + & + \\
\hline Pleopeltis pinnatifida & + & $0.9(1.8) 2.9$ & 0.3 & $10(18) 27$ & 3.5 & + & + & + \\
\hline Pleopeltis pleopeltidis & + & $1.7(2.3) 4.0$ & 0.2 & $14(21) 32$ & 3.9 & + & + & $+*$ \\
\hline Pleopeltis tweediana & + & $1.3(2.1) 2.9$ & 0.3 & $9(17) 23$ & 3.3 & + & + & + \\
\hline Polypodium chrysolepis & + & $0.6(1.0) 1.4$ & 0.1 & $13(19) 29$ & 2.6 & + & + & - \\
\hline Serpocaulon gilliesii & + & $0.6(1.1) 1.7$ & 0.2 & $12(20) 29$ & 3.6 & + & + & - \\
\hline
\end{tabular}

* Represents the main type.

are epiphytes and apparently there is no correlation between the width of the thickenings and the plant habit.

The widest thickenings per cell can be found in the epiphyte species, but not all epiphytes have thickenings bigger than the rupicolous species (Table 2).

The largest number of thickenings per cell appeared in Phlebodium areolatum (18-36), and this species has plants with leaves up to $1 \mathrm{~m}$ long. However, other species show different data independent of the plant size. For example, Campyloneurum tucumanense has fronds up to $1 \mathrm{~m}$ long and yet has a widely variable number of thickenings per cell (9-45), as does C. lorentzii with a frond length of $85 \mathrm{~cm}$ long with a similar range of length variation (940). These data suggest that there is no correlation between the frond length and the number of thickenings on the cell walls.

\section{Discussion}

According to Leroux et al. (2011), the presence of thickenings is not correlated with the habitat of the Aspleniaceae species. Our data for Polypodiaceae also showed that the number of thickenings per cell, and their width, are not related to the habit, habitat, or plant size. 
On the other hand, Leroux et al. (2011) demonstrated that thickenings support a monophyletic (BS $100 \%$ ) group in Asplenium. Unfortunately, our data for Polypodiaceae are preliminary to conclude any relation among the groups into the family based on the thickenings.

Because the regions of contact among the furcate thickenings are few (Figs. 4A, D), we called these thickenings 'anastomosing' (Figs. 4B, C) and not reticulate. On the other hand, the main kinds of thickenings observed were simple or furcated (Figs. 4A, D). Only in the epiphytic species of Microgramma, Phlebodium, and Pleopeltis are the anastomosing thickenings predominant; in Campyloneurum, another genus with epiphyte species, these anastomosing thickenings are few. According to Pandé (1935) and Ogura (1972), the thickenings in Polypodiaceae are helical and simple, whereas Leroux et al. (2011) classified the thickenings of Aspleniaceae into three types: simple, furcate, and reticulate.

Our results demonstrate the absence of pits in the thickenings. Leroux et al. (2011) also reported this for the Aspleniaceae. In the Polypodiaceae Pandé (1935) cited the presence of primary pit fields only in the cell wall between the thickenings.

About the chemical composition of secondary cell wall of roots, our results for different stains, fluorescence, and Phloroglucinol/HCl test revealed that the thickenings are basically formed of cellulose and that there is no deposition of lignin on them. Leroux et al. (2011) pointed out the same conclusions for Aspleniaceae. Additionally these authors commented that the thickenings present in the cell wall of the external cortical root zone are related to the mechanical protection of these small roots, acting as skeleton to the delicate roots of Aspleniaceae species to avoid root collapse during the dry periods in terrestrial, rupicolous, and epiphyte plants. The same interpretation might be applied to the species of Polypodiaceae here investigated. Among the analyzed species, all species of Pleopeltis (that are mainly epiphytic) showed pronounced development of the thickenings, probably as an adaptation to their revivescent ecology.

Given our results and those previously published (Schneider, 1997; Leroux et al., 2011), thickenings are known only for Eupolypods I (in Polypodiaceae), Eupolypods II (in Aspleniaceae) (Smith et al., 2006), respectively. Therefore, this character might be better explored for all Polypodiaceae members. It is highly probable that these structures appear in other members of Polypodiales, but more studies are needed to confirm this hypothesis. In fact, the presence of this structure in other groups of ferns, their types, and its evolution into ferns and lycophytes remains obscure.

\section{ACKNOWLEDGMENTS}

This project was funded by Fundación Miguel Lillo and by the Consejo de Investigaciones de la Universidad Nacional de Salta. We thank to all herbaria curators for allowing us to consult material; to Fabiana Ríos, Technician of the fern collection of Fundación Miguel Lillo, for help locating specimens at LIL. We are also in debt with Adriana Hladki and Esteban Sir, both from the 
Laboratorio Criptogámico of Fundación Miguel Lillo, for permission to use the Fluorescence Microscope, and the support of the technician staff of the LASEM, Universidad Nacional de Salta and LAMENOA, Universidad Nacional de Tucumán-CONICET for collaboration during the preparation of the samples. We also thank Robbin Moran (NY) for his critical comments on the first version of the manuscript, two anonymous reviewers and the Editor by suggestions to improve the paper.

\section{Literature Cited}

Bruno, G., L. Stiefkens, M. Hadi, I. Liscovsky, M. T. Cosa and N. Dottori. 2007. Efecto de la contaminación ambiental en la anatomía de la hoja de Ligustrum lucidum (Oleaceae). Bol. Soc. Argent. Bot. 42:231-236.

Christenhusz, M. J. M., X-C, Zhang and H. SchneIDER. 2011. A linear sequence of extant families and genera of lycophytes and ferns. Phytotaxa 19:7-54.

D’Ambrogio de Argüeso, A. 1986. Manual de técnicas den histología vegetal. Ed. Hemisferio Sur, Buenos Aires.

Hasebe, M., T. Omori, M. Nakazawa, T. Sano, M. Kato and K. Iwatsuki. 1994. rbcL gene sequences provide evidence for the evolutionary lineages of leptosporangiate ferns. Proc. Natl. Acad. Sci. U.S.A. 91:5730-5734.

Hasebe, M., P. G. Wolf, K. M. Pryer, K. Ueda, M. Ito, R. Sano, G. J. Gastony, J. Yokoyama, J. R. Manhart, N. Murakami, E. H. Crane, C. H. Haufler and W. D. Hauk. 1995. Fern phylogeny based on $r b c L$ nucleotide sequences. Amer. Fern J. 85:134-181.

Leroux, O., A. Bagniewska-Zadworna, S. K. Rambe, J. P. Knox, S. E. Marcus, E. Bellefroid, D. Stubbe, B. Chabbert, A. Habrant, M. Claeys and R. L. L. Viane. 2011. Non-lignified helical cell wall thickenings in root cortical cells of Aspleniaceae (Polypodiales): histology and taxonomical significance. Ann. Bot. 107:195-207.

Ogura, Y. 1972. Comparative anatomy of vegetative organs of the pteridophytes. Gebruder Borntraeger, Berlin.

PANDÉ, S. K. 1935. Notes on the Anatomy of xerophytic fern Niphobolus adnascens from the Malay Peninsula. Proc. Indian Acad. Sci. Sect. B: Phys. Sci. 1:556-564.

Prado, J. and R. Y. Hirai. 2010. A new combination in Pleopeltis and some nomenclatural notes related to illustrations validating fern names. Amer. Fern J. 100:189-194.

PRYer, K. M., A. R. SMith and J. E. SKOG. 1995. Phylogenetic relationships of extant ferns based on evidence from morphology and $r b c L$ sequences. Amer. Fern J. 85:205-282.

Pryer, K. M., H. Schneider, A. R. Smith, R. Cranflll, P. G. Wolf, J. S. Hunt and S. D. Sipes. 2001. Horsetails and ferns are a monophyletic group and the closest living relatives to seed plants. Nature 409:618-622.

Pryer, K. M., E. Schuettpelz, P. G. Wolf, H. Schneider, A. R. Smith and R. Cranfill. 2004. Phylogeny and evolution of ferns (monilophytes) with a focus on the early leptosporangiate divergences. Amer. J. Bot. 91:1582-1598.

Ranker, T. A., A. R. Smith, B. Parris, J. M. O. Geiger, C. H. Haufler, S. C. K. Straub and H. Schneider. 2004. Phylogeny and evolution of grammitid ferns (Grammitidaceae): A case of rampant morphological homoplasy. Taxon 53:415-428.

Romero, A. I. and D. W. Minter. 1988. Fluorescence microscopy: an aid to the elucidation of Ascomycetes structure. Trans. Brit. Mycol. Soc. 90:457-470.

Rothrels, C. J., M. A. Sundue, Li-Y, Kuo, A. Larson, M. Kato, E. Schuettpelz and K. M. Pryer. 2012. A revised family-level classification for eupolypod II ferns (Polypodiidae: Polypodiales). Taxon 61:515-533.

Ruzin, S. E. 1999. Plant microtechnique and microscopy. Oxford University Press, New York.

SCHNEIDER, H. 1997. Root anatomy of Aspleniaceae and the implications for systematics of the fern family. Fern Gaz. 15:160-168.

Schneider, H., A. R. Smith, R. Cranflll, T. E. Hildebrand, C. H. Haufler and T. A. Ranker. $2004 a$. Unraveling the phylogeny of polygrammoid ferns (Polypodiaceae and Grammitidaceae): Exploring aspects of diversification of epiphytic plants. Molec. Phyl. Evol. 31:1041-1063. 
Schneider, H., E. Schuettpelz, K. M. Pryer, R. Cranfill, S. Magallon and R. Lupia. 2004b. Ferns diversified in the shadow of angiosperms. Nature 428:553-557.

SchuEtTPElz, E. and K. M. PRYER. 2007. Fern phylogeny inferred from 400 leptosporangiate species and three plastid genes. Taxon 56:1037-1050.

Silva, G. B. da, M. Ionashiro, T. B. Carrara, A. C. Crivellari, M. A. S. Tiné, J. Prado, N. C. Carpita and M. S. BUCKERIDGE. 2011. Cell wall polysaccharides from fern leaves: Evidence for a mannan-rich Type III cell wall in Adiantum raddianum. Phytochemistry 72:2352-2360.

Smith, A. R., K. M. Pryer, E. Schuettpelz, P. Koral, H. Schneider and P. G. Wolf. 2006. A classification for extant ferns. Taxon 55:705-731. 


\section{$2 \mathrm{BHL}$ Biodiversity Heritage Library}

Hernández, Marcela A et al. 2013. "Helical Cell Wall Thickenings in Root Cortical Cells of Polypodiaceae Species from Northwestern Argentina." American fern journal 103, 225-240.

https://doi.org/10.1640/0002-8444-103.4.225.

View This Item Online: https://www.biodiversitylibrary.org/item/200536

DOI: $\underline{\text { https://doi.org/10.1640/0002-8444-103.4.225 }}$

Permalink: https://www.biodiversitylibrary.org/partpdf/231053

\section{Holding Institution}

Missouri Botanical Garden, Peter H. Raven Library

\section{Sponsored by}

Missouri Botanical Garden

\section{Copyright \& Reuse}

Copyright Status: Permission to digitize granted by rights holder

Rights: https://www.biodiversitylibrary.org/permissions

This document was created from content at the Biodiversity Heritage Library, the world's largest open access digital library for biodiversity literature and archives. Visit BHL at https://www.biodiversitylibrary.org. 